\title{
Re-Theorizing the Informal Economy in Western Nations: Some Lessons from Rural England
}

\author{
Colin C. Williams* \\ Management School, University of Sheffield, 9 Mappin Street, Sheffield S1 9DT, UK
}

\begin{abstract}
For much of the $20^{\text {th }}$ century, the informal economy in advanced western nations was depicted as a leftover from an earlier mode of production and disappearing from view. In recent decades, however, with the recognition that it persists and is even growing, it has been variously re-theorized as either a direct by-product of late capitalism, an alternative to formal work or a complement to the formal economy. To evaluate critically the validity of these rival theorizations of the relationship between formal and informal work in western economies and beyond, evidence from a study of 350 households in rural England is here reported. The finding is that although each and every theorization is wholly valid in relation to particular populations engaged in specific types of informal work, no one theorization fully captures the diverse and multiple relationships between formal and informal work. Here, in consequence, it is contended that only by using all of the existing theorizations will a finer-grained and more comprehensive understanding of the complex and multifarious relationships between formal and informal work be achieved. The result is a call to move beyond the conventional simplistic belief that the formal economy is everywhere replacing the informal economy and for greater recognition of the multifarious relations between formal and informal work in contemporary economies.
\end{abstract}

Keywords: Informal sector, household work practices, livelihoods, economic development, England.

\section{INTRODUCTION}

A recurring assumption in economic development is that over the long run of history, work has shifted from the informal into the formal economy. Whereas in past eras, laborers were seen to have toiled in their fields and homes on a subsistence basis and bartered, goods and services are from this perspective today viewed as largely produced, distributed and consumed through the formal economy. If economic history is read in this manner, then informal work is simply viewed as a residue or leftover of pre-capitalism and its persistence a sign of "backwardness" and "underdevelopment" [1,2]. Recently, however, this dominant and widespread view of informal work has been heavily criticized. The recognition that informal work is extensive and even growing in many western economies and beyond has led to a range of new perspectives regarding the relationship between formal and informal work. The aim of this paper, therefore, is to evaluate critically the validity of the rival representations that have emerged. To do this, evidence from a study of the relationship between formal and informal work in rural England will be used.

To commence, the first section will review the competing theorizations of the informal economy that portray such work either as a residue or leftover of some pre-formal era, a by-product of a new type of emergent formal economy, an alternative mode of work organization or a complement to

\footnotetext{
*Address correspondence to this author at the Management School, University of Sheffield, 9 Mappin Street, Sheffield S1 9DT, UK; Tel: +44 114222 3476; Fax: +44 1142223348 ;

E-mail: C.C.Williams@sheffield.ac.uk
}

formal work. To begin to evaluate the validity of these competing theorizations, the second section then introduces a 2002 survey of the nature of the relationship between formal and informal work in rural England and the third section then reports the findings. Revealing that each theorization is valid in relation to particular populations engaged in specific types of informal work, the final section then presents a conceptual framework that allows recognition of the multifarious relations between formal and informal work. The outcome will be a call to move beyond the simplistic belief that the formal economy is everywhere replacing the informal economy and for greater recognition of the multifarious relations between formal and informal work in contemporary economies.

Throughout this paper, and reflecting the widespread consensus, "informal work" will be defined as all work that is not "formal employment", that is, paid work registered with the state for tax, social security and labor law purposes. This defining of informal work in terms of what it is not reflects both the centrality of formal employment in contemporary society as well as how the informal economy is conceptually treated as a residual umbrella category that catches all forms of work that are not formal employment [3]. To bring order to the diverse types of work included in this umbrella category of "informal work", and akin to the wider literature [4-6], three broad types of informal work are here differentiated: "self-provisioning" which is the unpaid household work undertaken by household members for themselves or for other members of their household; "unpaid community work", which is unpaid work conducted by household members by and for the extended family, social or neighborhood networks and more formal voluntary and community groups, and ranges from kinship exchange, through friend- 
ship/neighborly reciprocal exchanges to one-way volunteering for voluntary organizations; and "paid informal work" which covers all monetized exchanges that are unregistered by or hidden from the state for tax, social security and/or labor law purposes but which are legal in all other respects $[7,8]$.

\section{THEORIZING THE INFORMAL ECONOMY}

To introduce the competing theorizations of the relationship between formal and informal work, four contrasting perspectives are here reviewed that presently have widespread purchase in the literature and cover the vast majority of views held.

\section{Informal Work as a Residue}

The residue perspective depicts goods and services as increasingly produced and distributed via the formal economy and informal work as disappearing due to a natural, organic and inevitable formalization of work. Informal work is thus a residue, a leftover from a pre-modern earlier mode of production, distribution and consumption, and a sign of "under-development", "traditionalism" and "backwardness". Formal work, meanwhile, is viewed as representing "progress", "development", "modernity" and "advancement" [9]. If informal work is greater in rural than urban economies, moreover, this is viewed as signaling the lagged adaptation of rural areas. Put another way, spatial differences in economies are conflated into a temporally sequenced normative hierarchy that depicts formal work as progressive and informal work as regressive.

Variously referred to as the "modernization", "dual economy", "residue" or "formalization" thesis [10-13], this common theorization of the relationship between formal and informal work is a classic example of what Derrida [14] terms hierarchical binary thought in that firstly, it conceptualizes formal and informal work as separate spheres constituted via negation and secondly, reads them in a normatively hierarchical manner in which the superordinate (formal work) is endowed with positive attributes and the subordinate (or subservient) "other" (informal work) with negative attributes and impacts.

The outcome is a temporal and hierarchical sequencing of these supposedly separate realms. Formal and informal work are temporally sequenced by reading the superordinate (formal work) as extensive and in the ascendancy and the subservient "other" (informal work) as primitive or traditional, stagnant, marginal, weak, and about to be extinguished. Formal and informal work are hierarchically sequenced, moreover, in that informal work is seen to signal "under-development", "traditionalism" and "backwardness". Formal employment, in contrast, is viewed as a sign of "progress", "development", "modernity" and "advancement".

Formal work is also viewed in this residue perspective as separate from informal work. This is clearly seen firstly, in those accounts that portray formal and informal enterprises as separate, secondly, in depictions of informal work as concentrated amongst individuals excluded from formal employment [15-17] and thirdly, representations of formal and informal work as occupying separate spaces in the economic landscape. At the micro-spatial level, that is, informal work is often consigned to the household while formal work occupies the separate sphere of the "employment-place" or "market". Scaling upwards, this residue thesis often assigns informal work to deprived neighborhoods in western nations and shanty towns in third world cities [18], while at the scale of global regions adherents to this residue thesis often depict informal work as inhabiting the peripheries, such as the new accession states in the European Union.

In sum, representing formal and informal work as a binary hierarchy, informal work is pre-modern, diminishing and existing in the margins, while the separate formal economy is extensive, expanding and progressive. A wealth of literature in recent decades, however, has contested various aspects of this residue thesis and in doing so, begun to reread the nature of the relationship between formal and informal work. On the whole, this is a result of the widespread recognition that informal work is extensive and even perhaps growing in contemporary economies. During the past decade or so, in consequence, the residue thesis has been often replaced by three competing theorizations, each of which is now considered in turn.

\section{Informal Work as a By-Product of Formal Work}

Drawing upon broader structuralist theorizations of economic restructuring, the structuralist theorization of informal work views such activity as growing rather than contracting in late capitalism, and formal and informal work as inextricably inter-twinned rather than separate. Informal work is growing, it is asserted, due to the emergence of a deregulated (neo-liberal) open world economy, which is encouraging a race-to-the-bottom in terms of labor standards [19-23]. On the one hand, the growth of informal work, particularly paid informal work, is viewed as a by-product of employers reducing costs by adopting informal work arrangements. This is manifested in the growth of subcontracting to those employing off-the-books workers under degrading, low-paid and exploitative "sweatshop-like" conditions, exemplified by the garment manufacturing sector $[24,25]$ and the self-employed. As Davis [26] puts it, contemporary capitalism is resulting in the re-emergence of "primitive forms of exploitation that have been given new life by postmodern globalization" [26, p. 186].

On the other hand, the growth of informal work more broadly defined to include unpaid work is in this structuralist theorization seen to result from the demise of the fullemployment/comprehensive formal welfare state regime characteristic of the mass production/mass consumption Fordist era. In the new post-Fordist era where flexible smallbatch production and consumption is replacing mass production/mass consumption, and permanent full-time labor becoming an ever smaller proportion of the overall labor force, those residual to capitalism are asserted to be no longer maintained as a reserve army of labor and socially reproduced by the formal welfare state but, instead, and as witnessed by reduced social spending, decanted onto the informal sphere where they eke out a survival. Informal work is thus asserted to be extensive in marginalized populations where it acts as a substitute for the formal economy in its absence. Informal work is engaged in by those involuntarily decanted into this sphere and undertaken out of necessity to survive [27]. 
This by-product thesis thus views informal work as a core and integral component of contemporary capitalism. As Fernandez-Kelly [28] puts it, "the informal economy is far from a vestige of earlier stages in economic development. Instead, informality is part and parcel of the processes of modernization" [28, p. 18]. This by-product theory thus rejects the temporal ordering of the residue thesis. However, it persists with the same normative hierarchical reading. Informal work is viewed as possessing largely negative attributes and formalization remains viewed the route to progress, albeit as a prescription for the trajectory of economic development rather than an organic and immutable view of the direction of change. This theory is exemplified by the International Labor Office [29] which recognizes that informal work is growing and inextricably inter-twinned with formal work and its "decent work" campaign prescribes formalization as the path to progress.

\section{Informal Work as an Alternative to Formal Work}

For others, this celebration of formalization is rejected and replaced by a privileging of informalization as the path to progress. Similar to the residue perspective, informal and formal work are here often seen as separate but unlike both the residue and by-product perspectives, informal work is portrayed as having positive attributes and impacts, and conducted as a matter of choice rather than due to a lack of choice [30]. As Gerxhani [31] argues, workers "choose to participate in the informal economy because they find more autonomy, flexibility and freedom in this sector than in the formal one" [31, p. 274].

Although conventionally associated with neo-liberals who portray informal workers as heroes casting off the shackles of an over-burdensome state [32-35], a similar position has been recently adopted by an array of postdevelopment, critical and post-structuralist scholars seeking to imagine and enact alternative futures for economic development beyond formalization and commodification [36-39]. In both approaches, the conventional normative portrayal of economic development as a process of formalization is countered with an alternative inverted view of development as a process of informalization.

\section{Informal Work as a Complement to Formal Work}

A fourth and final theorization of the relationship between formal and informal work again portrays informal work as possessing largely positive attributes and impacts, but reads formal and informal work as inextricably intertwinned rather than as separate. Indeed, formal and informal work are depicted as complementary in that they grow or decline in tandem, rather than one declining when the other grows [40]. This is argued not only at the global and national level where both are seen to grow or decline in tandem but also at the level of localities and households. Relatively affluent populations and households, who are the major beneficiaries of formal work, are also seen as the major beneficiaries of informal work, conducting not only more selfprovisioning, unpaid community exchange and paid informal work than households excluded from formal work but also more rewarding forms of informal work [41].

The consequence is that uneven development is not characterized as a polarization between formalized and informal- ized populations. Instead, uneven development is portrayed as a rift between "work busy" or "fully engaged" households with multiple formal jobs and high levels of participation in self-provisioning, unpaid community exchange and paid informal work, and "work deprived" or "dis-engaged" households excluded not only from formal but also informal work due to their lack of resources, skills and networks. "Progress" is thus portrayed not simply as a process of formalization but in terms of the capabilities of populations to engage in both formal and informal work.

Until now, although there have been numerous studies of the relationship between formal and informal work, including in rural areas of the western world [42-44], few studies have explicitly sought to evaluate critically the relevance of these competing theorizations. Here, the intention is to begin to do so. Is informal work in the rural areas of western nations merely a residue of some pre-formal era, a by-product of the formal economy, a complement to formal work or an alternative mode of work organization? Alternatively, are universal generalizations possible or do various theorizations apply to different types of informal work conducted by various population groups? To answer these questions, in 2002, a survey was conducted.

\section{METHODOLOGY: EXAMINING INFORMAL WORK IN RURAL ENGLAND}

To evaluate the rival theories of the relationship between formal and informal work in the rural areas of the western world, and given that previous studies identify that informal work significantly differs according to level of affluence [45, 46], a study was conducted of both affluent and deprived English rural areas. The UK government's Index of Multiple Deprivation, which ranks all 8,000-odd UK neighborhoods according to multiple deprivation indicators, was used to select a shortlist of localities which was then discussed with regional officers of the government's Countryside Agency (the sponsors of the research). The outcome was that two affluent or 'work-rich' localities, and three 'work-deprived' localities were chosen with a broad regional spread. The two work-rich localities were:

- Fulbourn, Cambridgeshire. This affluent commuter village just outside Cambridge is situated in the heart of the UK equivalent of "Silicon Valley" (known as "Silicon Fen") and is comprised of mostly large private sector housing. It is a classic "picture postcard" affluent commuter village.

- Chalford, Gloucestershire. With a population of some 5,600 , this affluent rural area in the Cotswolds has mostly private sector housing and low unemployment. A high proportion of the employed commute to cities some distance away (e.g., London, Bristol).

The three work-deprived localities, meanwhile, were chosen to represent varying types of deprived rural locality:

- St Blazey, Cornwall. Located in a popular tourist area, this relatively deprived population of some 6,100 is characterized by a mix of housing tenures, high unemployment and relative social isolation;

- Wigton, Cumbria. This mono-industrial rural community where one factory dominates the local labor 
market has little in-migration, a mix of housing tenures and low educational attainment, and

- Grimethorpe, South Yorkshire. This ex-coal mining village has very high unemployment, a uniform socioeconomic mix, low educational attainment, very little private sector housing and some breakdown of social solidarity following the decision to house exoffenders in social housing in the village.

The benefit of studying this diversity of rural localities is that, although the resultant empirical data is not representative of rural England as a whole, it enables different relationships between informal and formal work in particular localities or population-types to be identified.
Having selected these areas, a spatially stratified sampling procedure was then used to select households for interview in each area [47]. The researcher called at every $n^{\text {th }}$ dwelling in each street, depending on the number of households in each neighborhood and the number of interviews sought. For example, if there were 350 households in the locality and 70 interviews were sought, then every $5^{\text {th }}$ household was visited. If there was no response, then the researcher called back once. If there was still no response and/or they were refused an interview, then the $6^{\text {th }}$ house was surveyed (again with one call back), then the $4^{\text {th }}$ dwelling, $7^{\text {th }}$ and so on. This provided a spatially stratified sample of each locality. It ensured that the 70 interviews conducted in each locality were representative of the area and prevented a

Table 1. Characteristics of the Sampled Population: By Locality

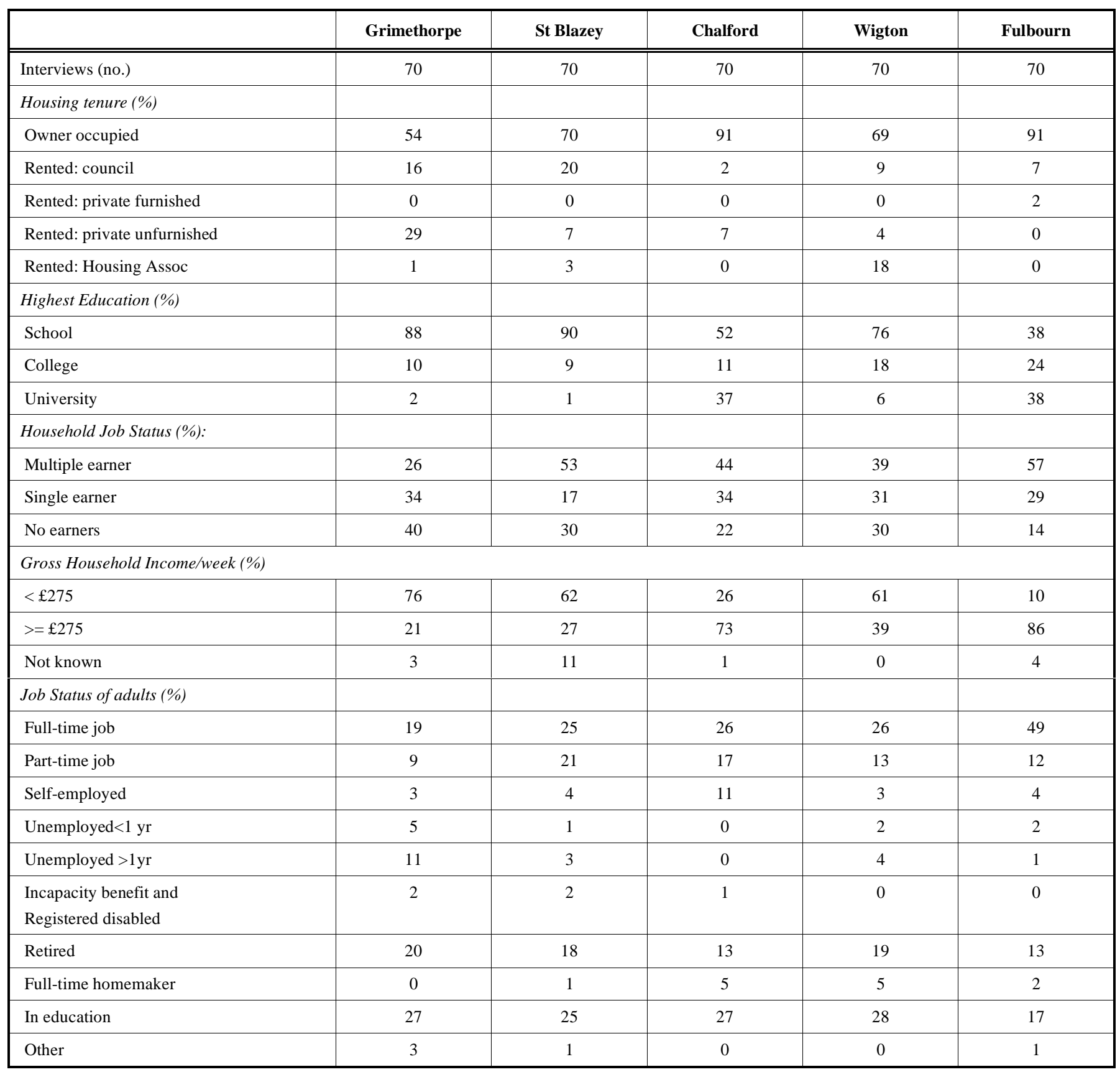

Source: Informal economy survey of English rural areas, 2002. 
skewed sample towards certain tenures, types of dwelling and different parts of each area being interviewed. The response rate was 15 per cent amongst the first choice households, rising to 37 per cent if the household on either side as alternative survey points is included and 61 per cent if the two households on either side are included and 90 per cent when the three households on either side of the original survey point are included. In each household, meanwhile, the "closest birthday" rule amongst people available for interview was used to select the respondent for interview.

Table 1 depicts the characteristics of the sampled population. Mirroring the above portraits of the areas, this reveals that the sampled populations in the work deprived localities of Grimethorpe, St. Blazey and Wigton do indeed have lower-incomes, higher rates of unemployment and lower levels of educational attainment than the affluent or workrich populations of Fulbourn and Chalford.

Learning from previous research on informal work, a direct survey method was used to gather data on the relationship between formal and informal work [48]. Informed consent was obtained from the study partners orally. The research, moreover, was subject to ethical review by the University of Leicester ethics committee. A pilot study using unstructured face-to-face interviews identified that interviewees found it difficult to recall where informal work had been both used and supplied, and that it was difficult to draw comparisons from the findings. As a result, a relatively structured interview method was devised based on a list of 43 common tasks (see Table 2), derived from the seminal study of household work practices by Pahl [49] on the Isle of Sheppey.

Firstly, therefore, the structured questionnaire evaluated the sources of labor used to get these 43 household services completed. The interviewee was asked whether each activity had been undertaken in the household during the previous five years/year/month/week (depending on the activity). If it had, they were asked: who had conducted the task (a household member, a relative living outside the household, a friend, neighbor, firm, landlord, etc); whether the person had been unpaid, paid or given a gift; and if paid, whether it was "cash-in-hand" or not as well as how much they had been given. Importantly, and unlike the earlier study by Pahl, they were then asked why they had decided to get the work done using that source of labor so as to enable their motives to be understood. Following this, the supply of undeclared work was examined. The interviewee was asked whether a household member had conducted each task for another household and if so, who had done it, for whom, whether they had received money, how much they had received and why they had decided to do the task. To capture other informal work received and supplied outside of these tasks, meanwhile, a series of open-ended questions were used. Here, the results are reported.

\section{RESULTS: INFORMAL WORK IN RURAL ENG- LAND}

Although this snapshot survey cannot measure whether there is a formalization or informalization of work in these rural localities, it can evaluate whether it is appropriate to represent informal work as a residue. Examining the 43 common domestic services surveyed, some 22 per cent were
Table 2. List of Tasks Investigated in the Informal Economy Survey of English Rural Areas

\begin{tabular}{|l|l|}
\hline House Maintenance & Home Improvement \\
\hline \hline - outdoor painting & - putting in double glazing \\
\hline - indoor painting & - plumbing \\
\hline - wallpapering & - electrical work \\
\hline - plastering & - house insulation \\
\hline - mending a broken widow & - putting in a bathroom suite \\
\hline - maintenance of appliances & - building a garage \\
\hline Housework & - building an extension \\
\hline - routine housework & - putting in central heating \\
\hline - cleaning windows outdoors & - carpentry \\
\hline - spring cleaning & Making and repairing goods \\
\hline - cleaning windows indoors & - making clothes \\
\hline - doing the shopping & - repairing clothes \\
\hline - washing clothes and sheets & - knitting \\
\hline - ironing & - making or repairing furniture \\
\hline - cooking meals & - making or repairing garden equipment \\
\hline - washing dishes & - making curtains \\
\hline - hairdressing & Gardening \\
\hline - household administration & - care of indoor plants \\
\hline Car maintenance & - outdoor borders \\
\hline - washing car & - outdoor vegetables \\
\hline - repairing car & - lawn mowing \\
\hline - car maintenance & \\
\hline Caring activities & \\
\hline - daytime baby-sitting & \\
\hline - night-time baby sitting & \\
\hline - educational activities & \\
\hline - pet care & \\
\hline
\end{tabular}

last acquired by households primarily through the formal economy, 5 per cent through paid informal work, 7 per cent through unpaid community exchanges and 66 per cent through self-provisioning. As such, informal work is not some minor residue or leftover in these rural localities.

Although the domestic services sphere is perhaps less formalized than other economic sectors, these data nevertheless reveal the shallow permeation of formalization in these English rural localities. At best, formal work is one amongst a plurality of economic practices used by households to secure their livelihoods. As such, even if this snapshot survey cannot decipher the changes over time in the formal/informal work balance, it does reveal that informal work is not some minor remnant existing only in the margins in rural England. 
If the residue thesis is incorrect as an overall depiction of the informal economy, then what is the relationship between formal and informal work? Is informal work a chosen alternative to formal work? Is it operating in a manner that complements the formal economy? Or are vast swathes of the population surplus to the requirements of contemporary capitalism being involuntarily decanted onto the informal economy to eke out their livelihood? To answer these questions, the multifarious types of informal work that exist in rural England are each analyzed in turn. This will reveal that although specific population groups engaged in particular types of informal work can be identified to support each theorization, no one theorization fully captures the multifarious relationships between formal and informal work across all types of informal work and all population groups.

\section{Self-Provisioning}

In these rural English localities, very few households pursue subsistence-oriented production in the sense of being largely detached from the formal economy and sourcing their goods and services on a self-provisioning basis. Examining solely the 1 per cent of households that do pursue selfsufficiency and recognizing the widespread move of most other households towards embedding themselves in the formal economy, the residue perspective appears a valid depiction of their situation, even if for some members of these households, self-provisioning is sometimes viewed more as an "alternative" to the formal economy than as a leftover from a previous era. Indeed, this residue theorization is further reinforced when those in subsistence-oriented households assert that their numbers are rapidly dwindling as the young leave this lifestyle and express a preference for formal market society.

However, self-provisioning does not only cover those households pursuing self-sufficiency. All households without exception use self-provisioning as part of their overall livelihood practices. Examining this wider activity, a very different picture emerges. Across the rural areas, two-thirds (66 per cent) of the 43 domestic services surveyed were last conducted using self-provisioning. Such informal work, therefore, is neither a rarity/residue. Nor is it the preserve of marginalized populations, as proponents of the residue and byproduct representations assert Although those in lowerincome areas conducted a slightly higher proportion of their workload using self-provisioning (67 per cent), some 64 per cent of tasks in affluent areas is also conducted using selfprovisioning.

The character of this self-provisioning, however, markedly varies. Relatively affluent households often choose to outsource routine domestic tasks so as to give them more time to engage in non-routine, creative and rewarding selfservicing activity, such as do-it-yourself activity in the home improvement and maintenance realm. The outcome is that self-provisioning is often qualitatively different across populations, comprised more of routine self-provisioning conducted out of necessity in deprived populations but nonroutine work of a creative and rewarding variety undertaken more out of choice in affluent populations. Even when deprived populations engage in non-routine self-provisioning, furthermore, it is more likely to be an emergency repair (e.g., when an appliance breaks down) conducted out of necessity while in affluent populations, it is more likely to be a home improvement project (e.g., building a garage, fitting a new bathroom) undertaken out of choice. Analyzing selfprovisioning in general, and non-routine self-servicing (doit-yourself activity) more particularly across affluent and deprived populations, therefore, provides support for the complementary thesis.

Table 3 reinforces this finding. It reveals that the populations of higher-and lower-income areas have contrasting preference/necessity ratios when conducting selfprovisioning. Although 46 per cent of self-provisioning in lower-income rural areas was primarily motivated by economic necessity, this was the case for just 11 per cent in the higher-income areas. Households, that is, often prefer to use self-servicing due to ease, choice or pleasure.

Examining solely routine types of self-provisioning especially in lower-income populations, in consequence, one finds support for the by-product theorization. Turning to self-provisioning in higher-income areas, which involves more non-routine self-provisioning such as do-it-yourself activity in the home maintenance and improvement sector, the finding is that a greater portion ( 89 per cent) is conducted out of choice, either because it was felt to be easier to do the task on a self-servicing basis ( 40 per cent), choice ( 22 per cent) or due to the pleasure they got from doing the work themselves ( 27 per cent). Examining self-provisioning, especially amongst relatively affluent populations, one therefore finds support for the theorization of informal work as a chosen alternative. Comparing self-provisioning between affluent and deprived populations, meanwhile, one finds support for the complementary thesis. Different theorizations are therefore valid depending on the population and type of work analyzed.

\section{Unpaid Community Work}

Although engagement in unpaid community exchange, akin to self-provisioning, is greater in lower-income popula-

Table 3. Motives for Self-Provisioning in the Household Services Sphere: By Type of Rural Area

\begin{tabular}{|l|c|c|c|}
\hline $\begin{array}{l}\text { Reason for Conducting Task on a } \\
\text { Non-Exchanged Basis (\%): }\end{array}$ & Lower-Income Rural Areas & Higher-Income Rural Areas & All Areas \\
\hline \hline Economic & 46 & 11 & 32 \\
\hline Ease & 24 & 40 & 30 \\
\hline Choice & 18 & 22 & 20 \\
\hline Pleasure & 12 & 27 & 18 \\
\hline
\end{tabular}

Source: Informal economy survey of English rural areas, 2002. 
tions, nearly all households engage in this kind of informal work. Again, however, households in deprived populations are more likely to use this work out of necessity and in the absence of alternatives whilst affluent populations are more likely to engage in such endeavor out of choice. Comparing people living in affluent and deprived rural localities, the former were twice as likely to assert that receiving work on this basis was a choice compared with those living in deprived localities. While unpaid community exchange in deprived populations thus provides support for the by-product thesis, in relatively affluent populations it provides more support for the representation of informal work as a chosen alternative.

Contrasting its variable configuration across populations in affluent and deprived localities, however, suggests that informal work complements formal work. Populations in affluent areas are more likely to conduct such work out of choice whilst populations in deprived areas are more likely to use it out of necessity and as a last resort.

\section{Paid Informal Work}

Paid informal work comes in many forms, ranging from an array of types of informal waged employment (18 per cent of all paid informal work reported), through various forms of self-employment (27 per cent of all paid informal work) to endeavor conducted on a one-to-one basis for friends, neighbors and kin (55 per cent).

Starting with informal waged employment, one finds considerable support for the by-product theorization. The vast majority was relatively low-paid work conducted by respondents out of necessity as a last resort. This applies to wholly informal waged work where the informal employee works without a formal contract and/or wholly off-the-books (5 per cent of all reported paid informal work), as well as quasi-formal employment where formal employees receive two wages from their formal employer, an official declared wage and an additional unofficial non-declared ("envelope") wage (13 per cent of all reported paid informal work). Whilst the former portrays the apparent separation of formal and informal work, the latter work arrangement displays how informal and formal work are inextricably interwoven and how informal work has become an inherent part of employment practices in late capitalism.

Turning to informal self-employment, meanwhile, one finds considerable support for the theorization of informal work as a positive "alternative" to formal work and resistance practice. This rural survey reveals that three-quarters starting-up an enterprise in the last three years had conducted some or all of their trade off-the-books and 13 per cent had not even registered their enterprises and were working wholly off-the-books (see Table 4). There are, however, marked geographical variations in the likelihood of entrepreneurs and the self-employed trading off-the-books, with a greater proportion trading off-the-books in deprived than affluent rural areas.

Why do they trade off-the-books? Two distinct groups can be identified. For a small group of self-employed marginalized from the formal labor market and living in the lowest-income quartile of households, such work is largely a survival tactic, and they work as general laborers, cleaners and so forth. These necessity-oriented informal selfemployed reflect the by-product theorization that represents informal workers as marginalized people off-loaded by capitalism. For a more affluent group engaged in relatively wellpaid informal self-employment often arising out of opportunities related to their formal job, using such work to "top up" their declared earnings, such work was conducted more out of choice. They did so because they did not believe in paying taxes, disbelieved that taxes would be used for the public good, wanted to keep money circulating locally, believed that informality marched hand-in-hand with rural culture, and so forth. This group thus provides strong support for the theorization of informal work as an alternative to formal work.

Turning to own account work for closer social relations, however, one finds support for yet another theorization. In

Table 4. Geographical Variations in Informal Entrepreneurship in Rural England: By Area

\begin{tabular}{|c|c|c|c|}
\hline & Affluent Rural & Deprived Rural & All Areas \\
\hline Sample Size & 140 & 210 & 350 \\
\hline$\%$ of total sample & 40 & 60 & 100 \\
\hline$\%$ of all off-the-books entrepreneurs surveyed & 53 & 47 & 100 \\
\hline \multicolumn{4}{|l|}{$\%$ of early-stage entrepreneurs who are: } \\
\hline - wholly legitimate & 33 & 13 & 24 \\
\hline - registered but conducting share of trade off-the-books & 60 & 64 & 63 \\
\hline - unregistered and wholly off-the-books & 7 & 23 & 13 \\
\hline \multicolumn{4}{|l|}{$\%$ of established self-employed who are: } \\
\hline - wholly legitimate & 36 & 18 & 28 \\
\hline - registered but conducting share of trade off-the-books & 54 & 69 & 61 \\
\hline - unregistered and wholly off-the-books & 10 & 13 & 11 \\
\hline
\end{tabular}

Source: Informal economy survey of English rural areas, 2002. 
previous studies, this type of paid informal work was asserted to be conducted for redistributive and/or social rationales [50]. This survey, however, reveals a continuum of rationales ranging from own-account work conducted for closer social relations mostly for economic necessity/survival rationales at one end, to work conducted mostly to help people out at the other end. For suppliers, these favors for closer social relations are sometimes conducted to make a little money "on the side" and sometimes to provide some service to people they know who would otherwise be unable to get the job undertaken and sometimes for a combination of both rationales. For consumers, meanwhile, people they know are often paid for undertaking some task in order to get a job done cheaper, to redistribute money to them in a way that does not appear to be "charity" and/or to develop or cement social ties.

Indeed, examining all instances where people provide favors to kin, friends and neighbors, some 40 per cent involved payment. Indeed, payment is often used to negate the need for reciprocity, especially in situations where the customer feels unable to return a favor due to their health, personal or financial situation. To seek to eradicate such paid favors, in consequence, would eliminate nearly half of all one-to-one favors and lead to a diminution of community self-help and thus social cohesion. This own-account informal work for closer social relations therefore provides support for the theorizations that attribute more positive characteristics to informal work, particularly the representation of informal work as a "complement" to formal work. This is because higher-income households give and receive some 41 per cent more own account work for and by closer social relations than the average household, whilst the lowestincome households receive and provide just one half of the paid favors as the average household, displaying how such informal work reinforces the socio-spatial disparities produced by formal work.

\section{DISCUSSION AND CONCLUSIONS: ARTICULAT- ING THE RELATIONSHIP BETWEEN FORMAL AND INFORMAL WORK}

This study of English rural localities reveals that different theorizations of the relationship between formal and informal work are appropriate for different types of informal work conducted by different populations. Examining the limited number of households pursuing subsistence production, for example, and how very few households remain untouched by the formal economy, the residue perspective appears valid. Indeed, this is further reinforced when older members of these subsistence-oriented households assert that their numbers are dwindling as the young leave the countryside in search of formal employment.

When considering other types of informal work, however, it is the theorization of informal work as a by-product of a new emergent form of capitalism that is using informal working arrangements to compete and off-loading onto the informal sector those no longer of use to it which is valid. Support for this comes not only when examining forms of informal waged employment such as "envelope wages" and sweatshop-like work, as well as routine self-provisioning, but also when wider trends are recognized such as that participation in many forms of informal work is greater amongst lower-income populations. Yet to depict all informal work in this manner is a misnomer.

Informal work, at least in some of its varieties, is often not a sphere inhabited purely by the marginalized, but rather, is a realm which reinforces, rather than reduces, the sociospatial disparities in formal work. This "complementary" theorization is exemplified in the realm of non-routine selfprovisioning for example, as well as the sphere of own account paid informal work conducted for closer social relations. There are also types of informal work that are a chosen "alternative" to formal work. Not only is there a culture of resistance to immersion in formal work, at least amongst a small minority engaged in subsistence production, but many engaged in informal entrepreneurship are doing so as a resistance practice, providing support for the portrayal of informal work as a chosen alternative.

The outcome is that although varying theorizations are appropriate as portrayals of different types of informal work conducted by particular populations, no one articulation fully captures the multifarious nature of the relationship between formal and informal work in rural England. There is need, therefore, to transcend the conventional view that these are competing theories. If one recognizes that each portrays particular types of informal work, then it becomes quickly obvious that by incorporating all of them a finer-grained more comprehensive understanding of the relationship between formal and informal work can be achieved.

How, therefore, might these theorizations be coupled together? Superficially, this does not appear achievable. On the one hand, in the theories of the informal economy as a residue and alternative, formal and informal work are read as separate, while those theorizing informal work as a complement to, and by-product of, formal work, view them as inextricably inter-related. Indeed, much of the contemporary literature that views formal and informal work as entangled vehemently opposes any notion of separateness [51].

In lived practice, however, this rural localities survey reveals that some forms of informal work are relatively entangled in formality and others relatively separate. When formal employees are paid a portion of their wages by their formal employer on a cash-in-hand basis, for example, this provides solid support for the depiction of formal and informal work as inextricably inter-related. So too does an analysis of non-routine self-provisioning. Throughout this survey when analyzing do-it-yourself tasks such as installing a bathroom, although self-provisioning might have been the primary labor, formal goods were used as well as formal labor to undertake parts of the overall job that the individual could not do, thus displaying how formal and informal work are intimately entangled at the level of individual tasks. Yet this intimate entanglement of formal and informal work is not apparent when examining subsistence-oriented households, many of whom only loosely and marginally engage with the formal economy, or when analyzing those starting businesses in the past three years working wholly off-the-books. There is a case to be made, therefore, for recognizing a spectrum of informal work ranging from varieties relatively separate from formal work (e.g., subsistence-oriented households) to those relatively inter-twinned with the formal economy (e.g., envelope wages, do-it-yourself). 
On the other hand, while the residue and by-product perspectives universally depict informal work as possessing negative attributes and impacts, the complementary and alternative approaches do the inverse. However, it is again wholly feasible to conceptualize a continuum of types of informal work ranging from those with mostly positive attributes and impacts (e.g., paid favors, unpaid community exchange, informal entrepreneurship) to those with largely negative attributes (e.g., exploitative sweatshop-like informal waged employment).

These contrasting theorizations, therefore, do not need to be seen as rivals. Instead, each can be read as valid for particular types of informal work conducted by particular populations, and which need to be integrated if a finer-grained and fuller understanding of the multifarious relations between formal and informal work is to be achieved. This is now starting to be recognized. How to synthesize them, nevertheless, has been little discussed. Fig. (1) graphically depicts how this might be accomplished. Firstly, it depicts a spectrum that ranges from forms of informal work that are relatively separate from formal work to types that are heavily embedded in the formal economy, and secondly, a spectrum of types of informal work ranging from those with largely negative attributes to those with largely positive attributes and impacts.

This re-theorization of informal work in Fig. (1) enables a clearer understanding of the multifarious relationships between formal and informal work. Conceptually, it enables the persistent debates between rival theories that contest each others viewpoint, despite talking about different forms of informal work, to be transcended. Its usage might also prevent adherents to a particular theory simply focusing upon those forms of informal work reinforcing their theory whilst ignoring those that do not. As Samers [52] highlights for example, those viewing informal work as a chosen alternative seem to display a myopic disregard for informal work that does not fit their depiction such as low-waged sweat- shop-like informal employment. This, however, is not unique to these commentators. It applies across all the theorizations.

Adopting this more integrative conceptual framework also enables more nuanced public policy approaches towards informal work to come to fruition. At present, a largely negative approach predominates, reflecting the dominance of the residue and by-product theorizations. This is particularly the case with regard to paid informal work where the dominant approach is to seek to eradicate such work by increasing the probability of detection and the penalties if caught. It is similarly the case when considering other forms of informal work. Few, if any, governments move beyond an employment-centered formalization discourse when discussing economic development. If the above conceptual framework were adopted, however, then this might help identify those forms of informal work that need to be eradicated and those that need to be either transformed into formal employment or tacitly condoned rather than adopting a "one size fits all" public policy approach which treats all types the same.

Perhaps most importantly, therefore, this more nuanced conceptualization might help the long-standing but simplistic arguments about whether formalization or informalization is the path to progress to be finally transcended. Rather than an "on-off" decision about whether formalization or informalization is the way forward for economic development, more nuanced finer-grained debates about the nature and direction of rural economic development could perhaps start to emerge that pursue a more "pick and mix" approach so far as various types of informal (and formal) work are concerned.

In sum, this paper reveals the need to move beyond the conventional simplistic belief that the formal economy is everywhere replacing the informal economy and for greater recognition of the multifarious relations between formal and informal work in contemporary economies. If this perspective is adopted, then the contention is that a more comprehensive understanding will be achieved. This will then allow a more refined and nuanced discussion to occur about the

Formal \& informal work

\begin{tabular}{|c|c|}
\hline $\begin{array}{l}\text { BY-PRODUCT } \\
\text { Examples: } \\
\text { - informal envelope wages } \\
\text { - 'sweatshop-like' informal employment }\end{array}$ & $\begin{array}{l}\text { COMPLEMENTARY } \\
\text { - Paid favors } \\
\text { - do-it-yourself activity }\end{array}$ \\
\hline Negative & Positive \\
\hline Attributes & Attributes \\
\hline $\begin{array}{l}\text { Examples: } \\
\text { - enforced subsistence-oriented households }\end{array}$ & $\begin{array}{l}\text { Examples: } \\
\text { - informal entrepreneurs } \\
\text { - voluntarily subsistence-oriented } \\
\text { households }\end{array}$ \\
\hline RESIDUE & ALTERNATIV \\
\hline
\end{tabular}

Formal \& informal work relatively separate

Fig. (1). The relationships between formal and informal work. 
way forward for rural economic development. Instead of debating whether either formalization or informalization is the route to progress and advancement, finer-grained understandings might begin to emerge adopting a more "pick and mix" approach so far as various types of informal (and formal) work are concerned. If this paper encourages others to investigate whether there are multifarious relations between formal and informal work in other geographical areas, then it will have achieved its objective. If it also encourages policymakers to move beyond treating the informal economy as a residue and as disappearing, and to begin differentiating between different kinds of informal work in various populations when considering the role of the informal economy in fostering economic development, then it will have more than fulfilled its intentions.

\section{ACKNOWLEDGEMENTS}

This study was funded by the Countryside Agency. I would like to thank Richard White and Theresa Aldridge for their research assistance in collecting the data. The usual disclaimers apply.

\section{REFERENCES}

[1] Geertz C. Old societies and new states: the quest for modernity in Asia and Africa. Glencoe, IL: Free Press 1963.

[2] Lewis A. The theory of economic growth. London: Allen and Unwin 1959.

[3] Latouche S. In the wake of affluent society: an exploration of postdevelopment. London: Zed 1993.

[4] Leonard M. Invisible work, invisible workers: the informal economy in Europe and the US. London: Macmillan 1998

[5] Pahl RE. Divisions of Labour. Oxford: Blackwell 1984

[6] Williams CC. Rethinking the "economy" and uneven development: spatial disparities in household coping capabilities in contemporary England. Reg Stud 2004; 38(4): 507-18.

[7] Renooy P. The informal economy: meaning, measurement and social significance. Amsterdam: Netherlands Geographical Studies Association 1990.

[8] Williams CC. Cash-in-hand work: the underground sector and hidden economy of favours. Basingstoke: Palgrave Macmillan 2004.

[9] Boeke JH. Economies and economic policy in dual societies. Haarlem: Tjeenk Willnik 1942

[10] Chen M. Rethinking the informal economy: linkages with the formal economy and the formal regulatory environment. In: GuhaKhasnobis B, Kanbur R, Ostrom E, Eds. Linking the formal and informal economy: concepts and policies. Oxford: Oxford University Press 2006; pp. 75-92.

[11] Fernandez-Kelly P. Introduction. In: Fernandez-Kelly P, Shefner J, Eds. Out of the shadows: political action and the informal economy in Latin America. Pennsylvania: Penn State Press 2006; pp.1-19.

[12] Williams CC. Formal and informal employment in Europe: beyond dualistic representations. Eur Urban Reg Stud 2009; 16(1): 147-59.

[13] Williams CC, Windebank J. The uneven geographies of informal economic activities: a case study of two British cities. Work Employ Soc 2002; 16(2): 231-50.

[14] Derrida J. Of grammatology. Baltimore: John Hopkins University Press 1967.

[15] Dimova R, Gang IN, Landon-Lane JS. The informal sector during crisis and transition. In: Guha-Khasnobis B, Kanbur T, Eds. Informal labour markets and development. Basingstoke: Palgrave Macmillan 2006; pp. 141-63.

[16] William CC, Windebank J. Informal employment in the advanced economics. London: Routledge 1998

[17] Tokman VE. Economic development and labor market segmentation in the Latin American periphery. J Int Am Stud World Aff 1989; 31(1): 23-47.

[18] Fernandez-Kelly P. Introduction. In: Fernandez-Kelly P, Shefner J, Eds. Out of the shadows: political action and the informal economy in Latin America. Pennsylvania: Penn State Press 2006; pp. 1-19.
[19] Amin A, Cameron A, Hudson R. Placing the social economy. London: Routledge 2002.

[20] Gallin D. Propositions on trade unions and informal employment in time of globalization. Antipode 2001; 19(4): 531-49.

[21] Hudson R. Economic geographies: circuits, flows and spaces. London: Sage 2005.

[22] Portes A. The informal economy and its paradoxes. In: Smelser NJ, Swedberg R, Eds. The handbook of economic sociology. Princeton: Princeton University Press 1994; pp. 141-63.

[23] Sassen S. Informalisation in advanced market economies. Geneva: International Labour Office 1997.

[24] Bender DE. Sweated work, weak bodies: anti-sweatshop campaigns and languages of labor. New Brunswick: Rutgers University Press 2004

[25] Espenshade J. Monitoring sweatshops: workers, consumers and the global apparel industry. Philadelphia: Temple University Press 2004.

[26] Davis M. Planet of slums. London: Verso 2006.

[27] Campbell RR, Spencer JC, Amonker RG. The reported and unreported Missouri Ozarks: adaptive strategies of the people left behind. In: Lyson T, Falk W, Eds. Forgotten places: uneven development in rural America. Lawrence, KS: University Press of Kansas 1993; pp. 30-52.

[28] Fernandez-Kelly P. Introduction. In: Fernandez-Kelly P, Shefner J, Eds. Out of the shadows: political action and the informal economy in Latin America. Pennsylvania: Penn State Press 2006; pp.1-19.

[29] International Labour Office. Decent work and the informal economy. Geneva: International Labour Organization 2002.

[30] Cross JC. Street vendors, modernity and postmodernity: conflict and compromise in the global economy. Int $\mathrm{J}$ Sociol Soc Policy 2000; 20(1): 29-51

[31] Gerxhani K. The informal sector in developed and less developed countries: a literature survey. Public Choice 2004; 120(2): 267-300.

[32] Maloney WF. Informality revisited. World Dev 2004; 2(6): 115978 .

[33] Snyder KA. Routes to the informal economy in New York's East village: crisis, economics and identity. Sociol Perspect 2004; 47(1): 215-40.

[34] Sauvy A. Le travail noir et l'economie de demain. Paris: CalmannLevy, 1984.

[35] De Soto H. The other path. London: Harper and Row 1989.

[36] Chakrabarty D. Provincializing Europe: postcolonial thought and historical difference. Princeton: Princeton University Press 2000.

[37] Escobar A. Encountering development: the making and unmaking of the third world. Princeton: Princeton University Press 1995.

[38] Gibson-Graham JK. A post-capitalist politics. Minneapolis: University of Minnesota Press 2006.

[39] Leyshon A, Lee R, Williams CC. Alternative economic spaces. London: Sage 2003.

[40] Beck U. The brave new world of work. Cambridge: Polity 2000.

[41] Fortin B, Garneau G, Lacroix G, Lemieux T, Montomarquette C. L'Economie souterraine au Quebec: mythes et realites. Laval: Presses de l'Universite Laval 1996.

[42] Jensen L, Cornwell GT, Findeis JL. Informal work in nonmetropolitan Pennsylvania. Rural Sociol 1995; 60(1): 91-107.

[43] Nelson MK, Smith J. Working hard and making do: surviving in small town America. Los Angeles: University of California Press 1999.

[44] Nelson MK, Smith J. Informal work in small town America. In: Marcelli E, Williams CC, Joassart P, Eds. Informal work in developed nations. London: Routledge 2009; pp. 178-201.

[45] Slack T. The contours and correlates of informal work in rural Pennsylvania. Rural Sociol 2007; 72(1): 69-89.

[46] Slack T, Jensen L. Informal work in rural America. In: Marcelli E, Williams CC, Joassart P, Eds. Informal work in developed nations. London: Routledge 2009; pp. 177-91.

[47] Kitchin R, Tate N. Conducting research in human geography: theory, practice and methodology. London: Prentice Hall 2001.

[48] Tickamyer AR, Wood TA. Identifying participation in the informal economy using survey research methods. Rural Sociol 1998; 63(2): 323-40.

[49] Pahl RE. Divisions of labour. Oxford: Blackwell 1984.

[50] Williams CC. The hidden enterprise culture: entrepreneurship in the underground economy. Cheltenham: Edward Elgar 2006. 
[51] Smith A, Stenning A. Beyond household economies: articulations and spaces of economic practice in postsocialism. Prog Hum Geogr 2006; 30(1): 1-14.
[52]

Samers M. The myopia of "diverse economies", or a critique of the "informal economy". Antipode 2005; 37(4): 875-86.

Received: December 16, 2009

Revised: January 16, 2010

Accepted: January 25, 2010

(C) Colin C. Williams; Licensee Bentham Open.

This is an open access article licensed under the terms of the Creative Commons Attribution Non-Commercial License (http://creativecommons.org/licenses/ by-nc/3.0/) which permits unrestricted, non-commercial use, distribution and reproduction in any medium, provided the work is properly cited. 